\title{
Результати резекції легень у хворих зі вперше виявленим деструктивним туберкульозом
}

Волошин Я.М., Калабуха І.А., Іващенко В.Є., Хмель О.В., Пилип'як О.М.

ДУ «Національний інститут фтизіатрії і пульмонології ім. Ф.Г. Яновського НАМН України», м. Київ, Україна

Обґрунтування. Хіміотерапія неефективна в 35 49 \% хворих зі вперше виявленим деструктивним туберкульозом легень. Покращити результати лікування можливо при своєчасному спрямуванні хворих на операцію.

Мета. Дослідити результати резекції легень у хворих зі вперше виявленим деструктивним туберкульозом легень.

Матеріали та методи. Проведено ретроспективний аналіз історій хвороб 238 пацієнтів зі вперше виявленим деструктивним туберкульозом легень, прооперованих у торакальному відділенні Національного інституту фтизіатрії і пульмонології. Осіб чоловічої статі було 143, жіночої - 95, вік - від 10 до 65 років. Із приводу туберкульом протягом 2-10 місяців лікувалися 59 пацієнтів, протягом 11-16 місяців - 42. Із приводу інфільтративного та фібрознокавернозного туберкульозу легень упродовж 4-17 місяців лікувалися 109 хворих. Через помилки діагностики 29 хворих не приймали хіміопрепаратів. У 78 пацієнтів із 3-9-го місяця хіміотерапії туберкульозний процес прогресував. Показаннями до операції були: туберкульома легень - 130 випадків, кавернозний туберкульоз - 5, фіброзно-кавернозний - 91, казеозна пневмонія - 12 . Дослідження виконувалося коштом держбюджету.

Результати. Усім хворим виконано операції: сегментектомія - 83, екстракапсулярне видалення туберкульоми - 27, лобектомія - 77, комбінована резекція - 23, пневмонектомія - 28. Резекції за допомогою новітньої технології - біологічного зварювання живих тканин - виконано 22 хворим. Післяопераційні ускладнення виникли у 25 осіб (10,5 \%) і були повністю усунені. Післяопераційна летальність становила 0,4 \%. Клінічне вилікування досягнуто у 237 хворих (99,6 \%). При патоморфологічному дослідженні препаратів відзначена виражена активність специфічного процесу в 183 осіб (77,0%). Найсприятливіший перебіг післяопераційного періоду відзначено у хворих із туберкульомами, які лікувалися до операції протягом 2-5 місяців, і фібрознокавернозним туберкульозом - 4-6 місяців. У віддаленому періоді спостереження (1-17 років) повна клінічна ефективність зберігалася в 97,3 \% пацієнтів.

Висновки. Своєчасне виконання резекцій легені з використанням нових хірургічних технологій дало змогу досягнути значного клінічного ефекту. 